\title{
Farmer views on climate change-a longitudinal study of threats, opportunities and action
}

\author{
Jaana Sorvali $^{1}$ (D) Janne Kaseva ${ }^{2} \cdot$ Pirjo Peltonen-Sainio $^{1}$
}

Received: 21 August 2020 /Accepted: 2 February 2021/Published online: 19February 2021

(C) The Author(s) 2021

\begin{abstract}
Any new policy measure aiming to mitigate climate change and support adaptation in agriculture is implemented at the farm scale. This makes a farmer the key actor. This study aimed to understand farmers' climate change views and reveal how farmers see their role, responsibilities and possibilities to mitigate and adapt to climate change. Furthermore, this study aimed to assess how various background variables and values associate with farmers' views in order to have novel and comprehensive on farmers' perspectives on climate change. Short-term changes in views were studied with a longitudinal framework. In total, 4401 farmers in Finland answered a standardized e-mail survey in spring 2018. A total of 2000 of them responded again in spring 2020. The respondents differed in gender, age, education, farming system, farm type, farm organization, farm size, revenue and region. The farmers were not a uniform group of citizens, and their views on climate change varied widely. For a Nordic, boreal zone country like Finland, climate change will bring not only challenges but also opportunities that may even strengthen the agricultural production. Such a "two-sided coin" causes confusion for farmers as indicated by this study. Climate change-induced risks often dominate the public dialogue with farmers. This study emphasizes the need for better balance between risks and opportunities not only in the dialogue with farmers but also with policy makers and all public discussion. Acknowledging farmers' views in planning the future climate policies for agricultural sector is elemental to ensure success in farm-scale implementation.
\end{abstract}

Keywords Climate change $\cdot$ Farmer $\cdot$ Agriculture $\cdot$ View $\cdot$ Longitudinal survey $\cdot$ Finland

Jaana Sorvali

jaana.sorvali@luke.fi

1 Natural Resources Institute Finland (Luke), Latokartanonkaari 9, FI-00790 Helsinki, Finland

2 Natural Resources Institute Finland (Luke), Tietotie 4, 31600 Jokioinen, Finland 


\section{Introduction}

Strong scientific proof supports the anthropogenic origin of climate change, and impacts on natural and human systems have already been detected (IPCC 2018). Agriculture, land use, land use change and forestry (LULUCF) and agriculture-related energy sector constitute around $20 \%$ of the greenhouse gas (GHG) emissions in Finland being the second largest source of GHG emissions after the energy sector (Ministry of Environment 2017). Agriculture will face severe challenges due to climate change, as, e.g., variable weather conditions, extreme weather events and higher risks for pest and disease outbreaks may be severe strains on agricultural production (Arneth et al. 2019). However, climate change is also projected to bring opportunities for Northern European agriculture, such as longer growing season and diverse crop choices, provided that the risks are timely managed (Peltonen-Sainio et al. 2018; Peltonen-Sainio et al. 2020). Hence, high-latitude agriculture may benefit from climate change but also needs to contribute to reduction of GHG emissions as defined in national and international climate policies and agreements. For achieving the reductions needed, farmers need to develop agricultural systems and adopt new management practices with a support provided by coherent and forceful agricultural and climate policies (Peltonen-Sainio et al. 2020). Farmers are the decision makers on agricultural practices at the farm level thus having a key role in climate change action of the sector. Therefore, it is crucial to understand their perceptions on climate change.

While scientific understanding of climate change has strengthened, and the evidence becomes even clearer, public understanding of climate change has not followed (Weber and Stern 2011). This has obvious impacts also for willingness to implement climate change policy measures. Values, environmental concerns, perceptions and attitudes play a central role in motivating environmental action although these pro-environmental intentions cannot be directly claimed to result in actual environmental friendly behaviour (Bardi and Schwartz 2003; Dunlap et al. 2000; Stern 2000). Still, psychologically oriented research can offer new insights into understanding climate change action (Weber and Stern 2011), also with farmers. Theory of values-belief-norms (VBN) by Stern (2000) was used as a starting point for research into farmers' climate change perceptions. The VBN theory examines how values, attitudes and understanding of the risks and consequences of environmental problems together with personal capabilities for action and personal norms explain pro-environmental action.

Research and literature on farmers' perception on climate change has increased steadily over the last decade (Karki et al. 2020), especially in the USA (see for example Arbuckle Jr. et al. 2013a, 2013b; Liu et al. 2014; Sanderson et al. 2018; Schattman et al. 2018). Buys et al. (2012) found that rural communities in Australia had conflicting views depending on whether they believed or not that climate change is of anthropogenic origin. Thereafter, studies on farmer beliefs in climate change have been published from Chile (Roco et al. 2015), New Zealand (Niles et al. 2016), South-Africa (Hitayezu et al. 2017), Bangladesh (Kabir et al. 2017), Nepal (Khanal et al. 2018) and Peru (Altea 2020).

Nguyen et al. (2016) found that differences in climate change perceptions of Sardinian farmers were dependent on socio-cultural and institutional settings and views on perceived impacts of climate change. The associations between farmers' climate change perceptions and actions were studied in Denmark (Jørgensen and Termansen 2016) and between perceptions and farmers' attitudes in Scotland (Barnes and Toma 2012) and Germany (Eggers et al. 2015; Jantke et al. 2020). In Sweden, farmers' climate change views were studied through framing (Asplund 2016) and in Norway with a representative survey (Brobakk 2018). Peltonen-Sainio 
et al. (2020) studied Finnish farmers' risk awareness, views and intentions to act by changing cultivation practices. However, in Finland, farmers' climate change views have not yet been thoroughly investigated.

The aim of this study, based on two large farmer surveys in Finland, was to understand:

1) What are Finnish farmers' general views on climate change, as well as its risks and opportunities induced on agriculture?

2) How do the Finnish farmers see their responsibilities and possibilities to mitigate and adapt to climate change in agriculture?

3) Do climate views, perceived responsibility, or possibility to mitigate and adapt differ based on demographics or practiced farming systems?

4) Has there been any change in any of the above views between 2018 and 2020 and, if so, in which farmer groups?

5) Are the different climate views associated to each other, and how?

6) What is the role of personal values in shaping climate change views? and

7) What are the implications of farmers' views for future climate action in agriculture?

\section{Materials and methods}

\subsection{Participants}

Two surveys were carried out, the first in the spring of 2018 and the second in the spring of 2020. In 2018, a standardized e-mail survey was sent to all the Finnish farmers with an e-mail address in the current Finnish Food Authority (formerly Finnish Agency for Rural Affairs) database in 2016. Out of the total of 47,688 (80\%) Finnish farmers in 2018 (Natural Resources Institute Finland 2019), the survey was successfully sent to 38,091 farmers. The remaining $20 \%$ of farmers could not be reached due to a lacking, changed, or misspelled address. Altogether, 4401 farmers answered the survey and the response rate was $12 \%$. In 2020, the second survey was sent to the farmers who responded to the first one, of which $45 \%$ responded to the second survey. The surveys were part of a larger data inquiry concerning farmers' values, views on farming practices and the future of agriculture in Finland. Responding was voluntary. It was obligatory to answer all the questions in both surveys, so there were no missing data. Some of the background variable data (farm size, farm type and region) were drawn from the Finnish Food Authority database and combined with the survey data via farm's identity code, thus leaving only minor gaps to the background variable data.

The cover letter on the first survey instructed that the person mainly responsible for the decision making at the farm should answer the questions. For the second survey, it was asked that the same person, who responded in 2018, would answer again. As a result, most of the respondents were male (2018: $87 \%$ and 2020: 89\%) and their average age was 51 years in $2018(S D=11.0$, range $18-78$ years $)$ and 54 years in $2020(S D=10.4$, range 26-81 years). The average farm size was 51 ha $(S D=50.2)$ and $15 \%$ were organic farms in 2018 and 60 ha $(S D=61.7$ ) with $16 \%$ organic farms in 2020 (Appendix 1).

In accordance with the farm type structure in Finland, most of the respondents were cereal producers (2018: $43 \%$ and 2020: 43\%) and the second largest group were dairy farmers (2018: $18 \%$ and 2020: 18\%). The group "others" was quite large in both surveys, and it consisted of farms specialized in sheep, horses and sole grass production, bee farming, silviculture, 
landscape management, land renting, tourism and contracting business with farm machinery. Respondents covered all geographical areas of Finland and the education of the respondents was quite high: $65 \%$ of the 2018 respondents had completed secondary education and $25 \%$ had a university degree, whereas among the 2020 respondents, the numbers were $62 \%$ and $31 \%$, respectively. Economic revenue for the agricultural production was 100,000 euros or less for $66 \%$ of respondents in both years.

When the background variable distributions of the respondents in 2018 were compared to those of all farmers in Finland, no significant distortions of representativeness were found regarding gender, age, farming system, farm size, farm organization, farm type and geographical area of the respondents. According to this non-response analysis, including a possible coverage error, our data for 2018 was interpreted as a representative sample of the Finnish farmer community. For education, comparable data was difficult to find, and with the classifications at hand, the survey respondents seemed to have more vocational schooling than Finnish farmers in total. For economic revenue, our sample was under-presented in the under 20,000 euros group, which might have some effects on results. Younger farmers were underrepresented and university-educated farmers slightly overrepresented in the 2020 data compared to the 2018 data. Otherwise, no distortions were found between the two datasets.

\subsection{Instruments}

The farmers answered questions regarding their views on climate change, perceptions of climate change-related risks and opportunities, responsibility and capacity to act in climate change mitigation and adaptation. Similar to Arbuckle Jr. et al. (2013a, 2013b), we were interested in the farmers' views on the anthropogenic origins of climate change and thus included this element to the general climate change view questions. The statements and scales are presented in Appendix 2. Different levels of distance of the actor to the needed action were used in the questions to measure the effect of psychological distance (the geographic, temporal and social distance together with high uncertainty) of climate change (Spence et al. 2012). Here, the psychological distance refers to how close the action is to the respondent. The different levels of distance used here were (1) the general level "agriculture" or "agricultural sector" (the most distant to respondent); (2) the farmer level; and (3) personal level "I" or "my" (the closest to respondent).

Basic human values are defined as "desirable trans-situational goals, varying in importance, that serve as guiding principles in the life of a person or other social entity" (Rokeach 1973; Schwartz 1994). A large variety of attitudes and preferences can be predicted from selfreported values (Sagiv et al. 2017), and there is also a connection between values and actual behaviour mediated through beliefs and norms, as described in the VBN theory (Stern 2000; Bardi and Schwartz 2003). Finnish farmers' values were measured using the theory of basic human values (Schwartz et al. 2012), and this method and its results are thoroughly presented in Sorvali et al. (2020). Values and their connections to environmental concern and action have been thoroughly studied, and especially self-transcendence values of universalism and benevolence are closely positively and self-enhancement values associated negatively with concerns regarding the environment (Hansla et al. 2008; Schultz et al. 2005; Stern 2000). Finnish farmers are strongly motivated by self-transcendence and universalism values in all groups studied, but differences still exist (Sorvali et al. 2020). For the purposes of studying the connections between values and climate change views, sum variables were used as dependent variables for climate change as an opportunity, felt responsibility and felt possibility to act for 
both mitigation and adaptation statements (Appendix 3). For values, the three universalism values (universalism nature, universalism concern and universalism tolerance), two benevolence values (benevolence caring and benevolence dependability), the self-enhancement values (achievement, dominance power and dominance resources), hedonism, security societal and security personal were used in analysis as independent variables (Appendix 4) as there might also be other motivations besides environmental ones motivating pro-environmental behaviour (Price and Leviston 2014). Security values were included because for Finnish farmers, security societal was placed, against the original theory, next to benevolence values (Sorvali et al., under review). Values were measured by 57 statements (three for each value) or descriptions of motivations. The question stated was: "How much like you is this person?" A scale where $1=$ "Not at all like me" and $6=$ "Very much like me" was used.

\subsection{Statistical analysis}

Parametric independent samples $t$-test and one-way analysis of variance (ANOVA) were used to evaluate differences in group means in all statements. When there were more than two groups, the Tukey's honestly significant difference (HSD) test was used for post hoc comparison. It tests all pairwise differences and controls the probability of making one or more type I errors. Differences in group means are reported from the 2018 survey data only. Change of views in different farmer groups from 2018 to 2020 was studied by comparing the means of the same groups between the two surveys. The difference between answers of the same respondents was calculated by subtracting the answer of 2018 from the corresponding answer of 2020. Pearson's $r$ was used to test the combined variability of different variables. Before correlation analysis, sum variables were formed and their internal consistencies were evaluated using Cronbach's alpha.

Parametric test was used, even though the 5-point Likert scale is ordinal. Although ANOVA and HSD both assume a normal distribution of observations and equal variances of the groups, the risk of violations of these assumptions was reduced notably because of the large sample size $(N=4401$ and $N=2000)$ (de Winter and Dodou 2010). The analyses were performed using the SAS Enterprise Guide 7.15 software package (SAS Institute Inc., Cary, NC, USA) and IBM SPSS Statistics for Windows, version 25 (IBM Corp., Armonk, NY, USA).

\section{Results}

\subsection{Farmers' views on climate change, opportunities and risks}

Almost all Finnish farmers agreed that climate change is occurring (Fig. 1, Appendix 3 ), as in 2018 only $1 \%$ of them answered that climate change is not occurring and $2 \%$ that there is not enough evidence to make a firm judgement. In spite of this, there was a lot variation concerning the cause for climate change. Only $33 \%$ of the farmers agree that climate change is of anthropogenic origin, while majority (64\% in 2018 and $68 \%$ in 2020) stated that natural changes cause climate change: either alone or together with human influence. The belief in anthropogenic climate change declined by 0.09 percent unit $(p \leq 0.0001)$ from 2018 to 2020 with the respondents answering to both surveys (Appendix 3). 


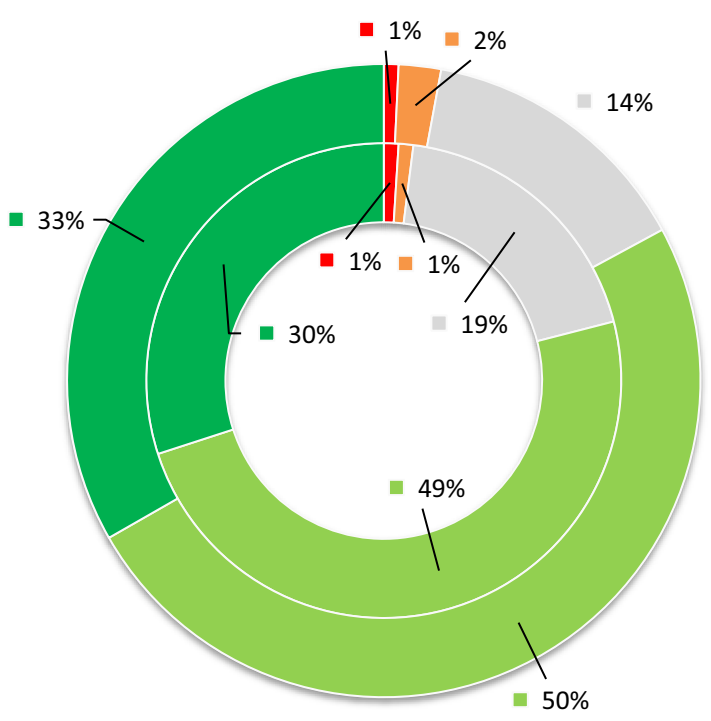

n Climate change is not occurring

Not sufficient evidence to know with certainty whether climate change is occurring

Climate change is occurring, caused mostly by natural changes

- Climate change is occurring, caused equally by natural and human activities

- Climate change mostly caused by human activities

Fig. 1 Finnish farmers' climate change belief in 2018 (outer ring, $N=4397, \overline{\mathrm{X}}=4.13, \mathrm{SD}=0.73$ ) and in 2020 (inner ring, $N=2000, \overline{\mathrm{X}}=4.06, \mathrm{SD}=0.78$ ). Respondents were asked to "Choose a statement that best describes your opinion"

Women agreed with anthropogenic origin of climate change more than men did (Appendix 5). Differences between age groups were found, but only the youngest ( $<30$ years) differed from the group of 51-70 years old. The higher educated farmers believed more frequently in the anthropogenic origin of climate change than the less educated farmers. Organic farmers considered climate change more often to be of anthropogenic origin than conventional farmers, as did farmers with smaller farms when compared to those with bigger farms. Geographically, belief in anthropogenic climate change was higher in Åland, Southern and Eastern parts of Finland than in Western and Northern Finland. Views did not differ based on farm type.

Farmers' views on the anthropogenic origin of climate change had changed from 2018 to 2020 in most of the background variable groups when we studied the change within the groups (Appendix 8). Women showed no statistically significant change in their views, but men believed less in the anthropogenic origins of climate change than before. The age groups of 31-50 and 51-70 also showed a decline in mean, as did the vocationally trained farmers, organic and conventional farmers and all the farm size groups. Cereal farmers, special crop farmers and the farm type "other" together with geographical groups of Western and Eastern Finland also showed a decline in mean in 2020 compared to their mean scores in 2018.

Climate change is clearly understood as a threat to global agriculture, as $74 \%$ of the farmers agreed and only 7\% disagreed with this statement in 2018 (Appendix 3, Fig. 2). For Finnish agriculture, the view was different as a third of farmers considered climate change a threat and another third disagreed it to be a threat. There was no change in the threat views of farmers from 2018 to 2020 (Appendix 3). Women and organic farmers considered the threat to be more serious both globally and locally than men and conventional farmers (Appendix 5). No differences were found between other groups regarding global threat. The youngest farmers $(<$ 30 years) differed from the age groups of $31-50$ and 51-70 years in their views of climate change as a threat to Finnish agriculture, as did smaller farms compared to bigger farms. No 
differences were found based on education, farm type and region in respect to the threat for Finnish agriculture.

No significant changes were found when comparing the changes within the groups in 2018 and 2020, with respondents answering both surveys regarding their views on global threat (Appendix 8). The change in views on climate change being a threat, both globally and locally, was negligible, as only dairy farmers and farmers in Western part of Finland had changed their views, considering climate change less of a threat to Finnish agriculture in 2020 than in 2018.

Some Finnish farmers also acknowledged that climate change will bring opportunities to Finnish agriculture besides the threats, although personal opportunities were seen smaller than the general ones (Fig. 2, Appendix 3). According to 52\% of the farmers, climate change creates new opportunities for Finnish agriculture, and $42 \%$ think that the yields will increase in Finland due to climate change. However, only $19 \%$ of the farmers agreed that their own farm will benefit from climate change and $12 \%$ expected climate change to bring economic benefits. There was a lot of uncertainty among the farmers, as a large share of them neither disagreed nor agreed, although this might also reflect hesitancy to state one's true opinions. The change in means from 2018 to 2020 was positive for all the opportunity statements (Fig. 2, Appendix 3).

Genders did not differ in their views that climate change creates new opportunities for Finnish agriculture, but men were more positive on all the other opportunity statements (Appendix 5). Age groups did not differ with respect to the opportunity statements. Farmers with higher education answered more frequently than those with lower education that climate change creates new opportunities for Finnish agriculture, that yields will increase and that they will economically benefit from climate change. Conventional farmers considered more often than organic farmers that climate change will be more beneficial than harmful to agriculture in

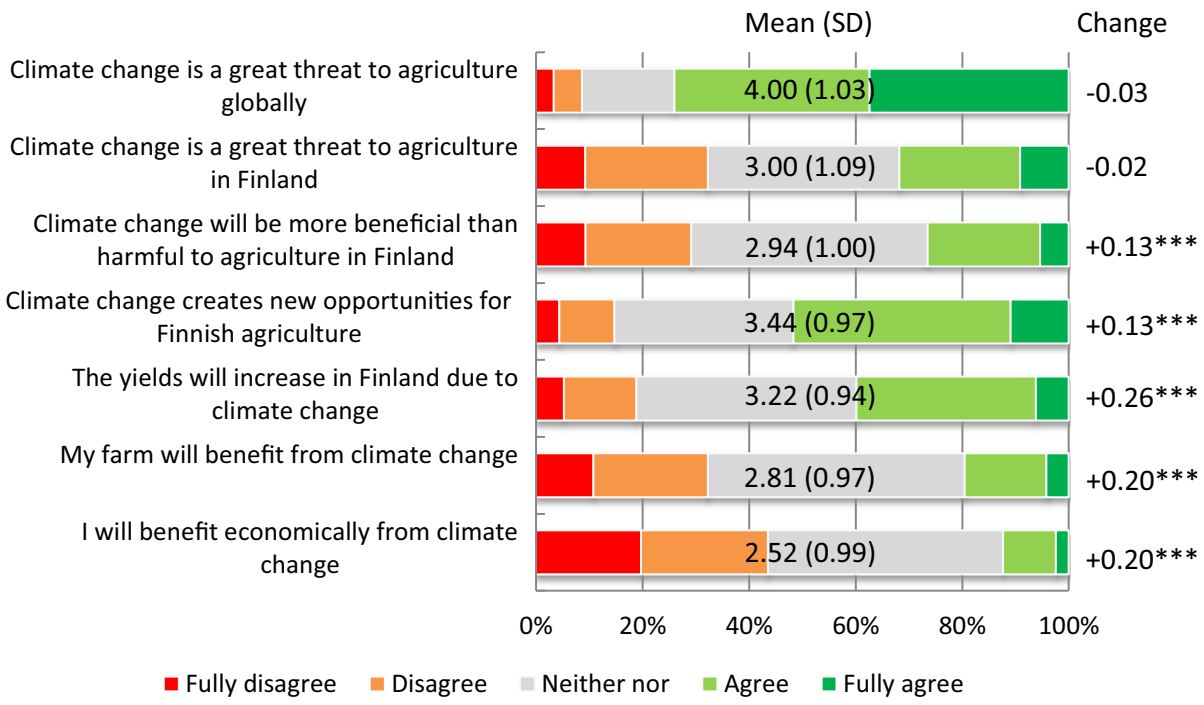

Fig. 2 The distribution, mean, and standard deviation (SD) of farmer's answers to questions related to climate change-induced threats and opportunities for Finnish agriculture shown in bars for $2018(N=4397)$. The respondents were asked "What do you think about the following statements?" Answers were measured by a 5 -point Likert scale ( $1=$ fully disagree, $2=$ disagree, $3=$ neither agree nor disagree, $4=$ agree, $5=$ fully agree). The same statements were repeated in 2020, and the change in mean and statistical significance for the respondents who responded to both surveys $(N=1966)$ is shown on the right. The statistically significant differences are indicated by $* * * P<0.001, * * P<0.01$, and $* P<0.05$ 
Finland. Organic farmers were more positive that climate change will create new opportunities for Finnish agriculture. Farmers with bigger farms (100 ha or more) saw more benefits from climate change than those with smaller farms, but no differences between farm types were found. As for regions, the only differences were in the question concerning personal economic benefit; farmers in the Northern Finland were more pessimistic than those in the other regions.

Changes were positive and marked between the two surveys in almost all groups for statements on climate change as an opportunity (Appendix 8). Exceptions were women, < 30 and $\geq 71$ years old farmers, the "others" group in education, horticultural producers and farmers from Åland, as they had not changed their views in any of the opportunity statements.

\subsection{Responsibility to mitigate and adapt to climate change in agriculture}

In general, farmers responded that actions should be taken in agriculture to mitigate climate change, but there was, again, a lot indecisiveness among farmers (Fig. 3). The psychological distance trend (agricultural sector's view, farmers' general view and personal view) was of

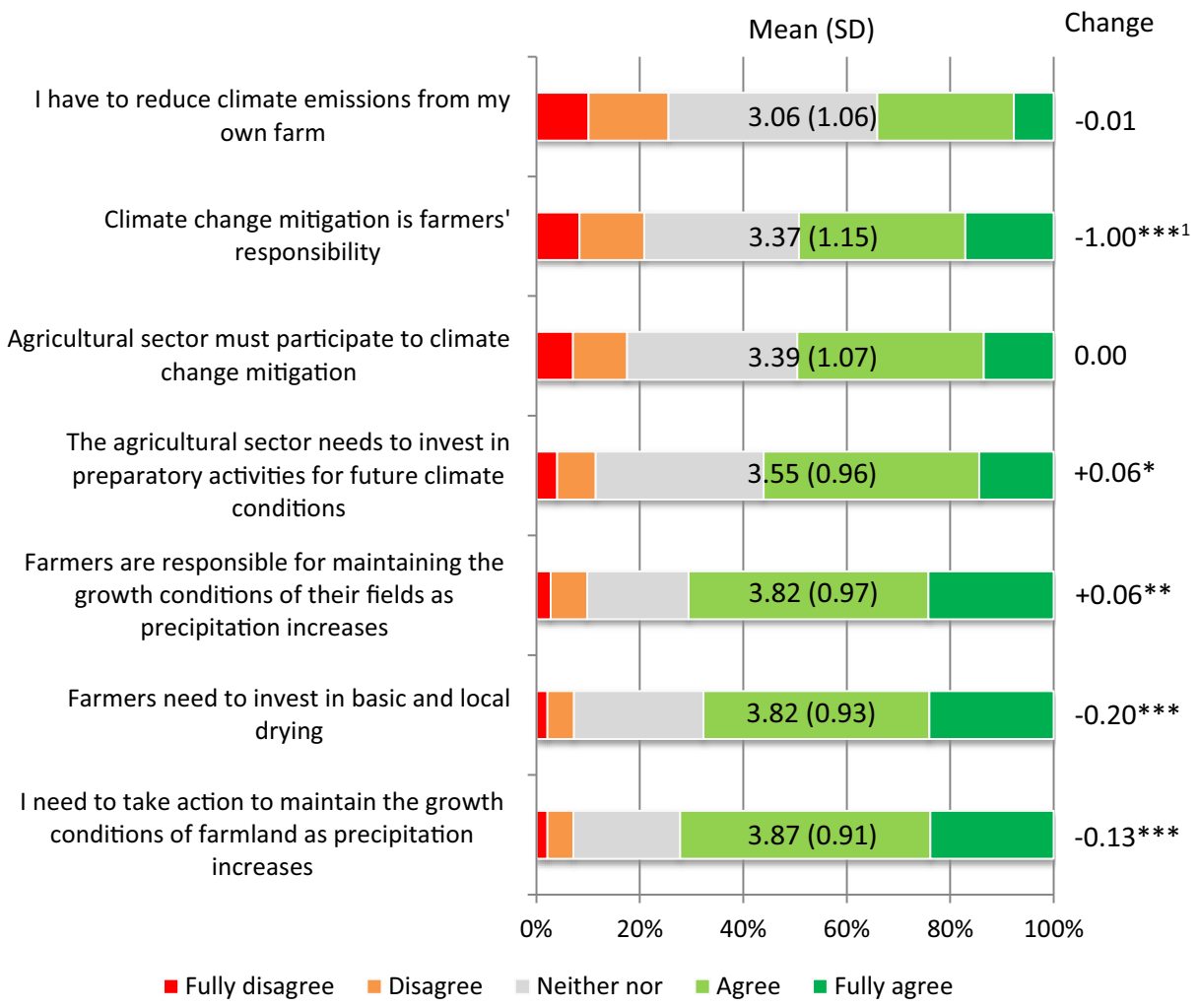

Fig. 3 The distribution, mean, and standard deviation (SD) of farmer's answers to questions related to responsibility of climate change mitigation and adaptation shown in bars for $2018(N=4397)$. The respondents were asked "What do you think about the following statements?" Answers were measured by a 5-point Likert scale $(1=$ fully disagree, $2=$ disagree, $3=$ neither agree nor disagree, $4=$ agree, $5=$ fully agree). The same statements were repeated in 2020, and the change in mean and statistical significance for the respondents who responded to both surveys $(N=1966)$ is shown on the right. The statistically significant differences are indicated by $* * * P<0.001$, $* * P<0.01$, and $* P<0.05$. ${ }^{1}$ The statement was formulated negatively in 2018 : "Climate change mitigation is not farmers' responsibility" and then the scale was rotated for analysis 
importance as more responsibility for action was required in case the action was further away from the farmer level. When half of the farmers supported the participation of the agricultural sector to climate change mitigation and $49 \%$ thought mitigation is farmers' responsibility in 2018 , only $34 \%$ thought that they should reduce emissions at their own farms.

There were no changes in overall farmer responses from 2018 to 2020 concerning the agricultural sector participation to mitigation and personal reduction of emissions. However, the statement "climate change is farmers' responsibility" saw a noteworthy decline in the farmers' responsibility statement (Fig. 3, Appendix 3). In 2018, the statement was presented as a negation (climate change is not farmers' responsibility) and then rotated for comparative analysis. The change was so high that we need to credit some of that change to the different formulation of the question.

There was a similar distance trend as described above when considering the differences between groups in all the mitigation statements (Appendix 6). More support was given to the agricultural sector's participation to climate change mitigation by women, 51-70 year olds, university-educated farmers, organic producers, smaller farm owners and horticultural producers as well as farmers from Åland than did their counterpart groups (i.e. men, younger, less educated and conventionally farming, larger farms owners, dairy and pig farmers and farmers from mainland Finland) (Appendix 6). Similar trend was found with other statements on mitigation responsibility, with the exception of farm type that did not differ regarding personal and farmer responsibility for mitigation.

Organic farmers and the smallest farms had changed their view slightly towards more negative and pig farmers more positive concerning agricultural sector's participation to mitigation when looking at the changes within the background variable groups from 2018 to 2020 (Appendix 9). Furthermore, the smallest farms had a more negative view on the personal mitigation responsibility, while all the other groups had the same views as previously. Changes were found in almost all background variable groups in the statement concerning farmers' responsibility on mitigation. The views had become more negative compared to 2018 (e.g. women -1.04 percent unit; 30 and under year group -1.14). Although there was a small difference in the formulation of the statement from 2018 to 2020, that explains at least partly the seemingly large shifts in opinions.

Support for climate change adaptation actions was clearly higher than that for mitigation (Appendix 3, Fig. 3.). Farmers considered personal responsibilities to be higher for adaptation than for mitigation: $72 \%$ thought that they have to take adaptation action and $70 \%$ that they need to invest in adapting to future precipitation increases. The overall change in adaptation action views between 2018 and 2020 was slightly positive with farmers' own responsibility for maintaining soil conditions and agricultural sectors need to invest for preparatory activities (Appendix 3, Fig. 3). However, their views were more negative in 2020 concerning their own action on soil management and investment for water management than in 2018.

Men and the owners of the largest farms supported farmer's responsibilities for maintaining soil conditions and investment on basic and local drying of the fields more than women and owners of smaller farms did. There were no differences between the other groups (Appendix 6). Need for personal adaptation action did not differ depending on gender but support for farmer's own investment was higher among men, while sector level investments among woman farmers. No systematic pattern was found between education groups and regions towards all adaptation statements, despite significant differences. Organic producers and farmers with bigger farm units tended to give more support to adaptation actions than 
conventional or smaller farms did. The adaptation statements did not differ depending on farmer's age (Appendix 6).

Views towards adaptation responsibility within groups were clearly more negative in 2020 than in 2018 (Appendix 9). Views on mitigation divided respondents into clearly definable opposing groups (men/women, organic/conventional and high/low education), whereas views on adaptation had changed towards a more negative direction for personal adaptation action and need for farmers' investment.

\subsection{Possibilities to mitigate and adapt to climate change in agriculture}

In general, farmers' views on their possibilities to influence climate change mitigation were encouraging (Fig. 4, Appendix 3). A large majority of farmers (65\%) agreed that farmers can mitigate climate emissions with farming practices and that their own farming choices influence climate emissions (54\%). Respondents were, however, a bit more uncertain with their own possibility to mitigate at their own farm (40\% agreed; 22\% disagreed) (Fig. 4). All responses to mitigation possibility statements had become more positive from 2018 to 2020, especially farmer's mitigation possibilities at their own farm (+0.23 percent unit) (Fig. 4, Appendix 3).

Responses for the four opportunities statements did not differ depending on age and farm type (Appendix 7). Women farmers were more positive than men on mitigation opportunities,

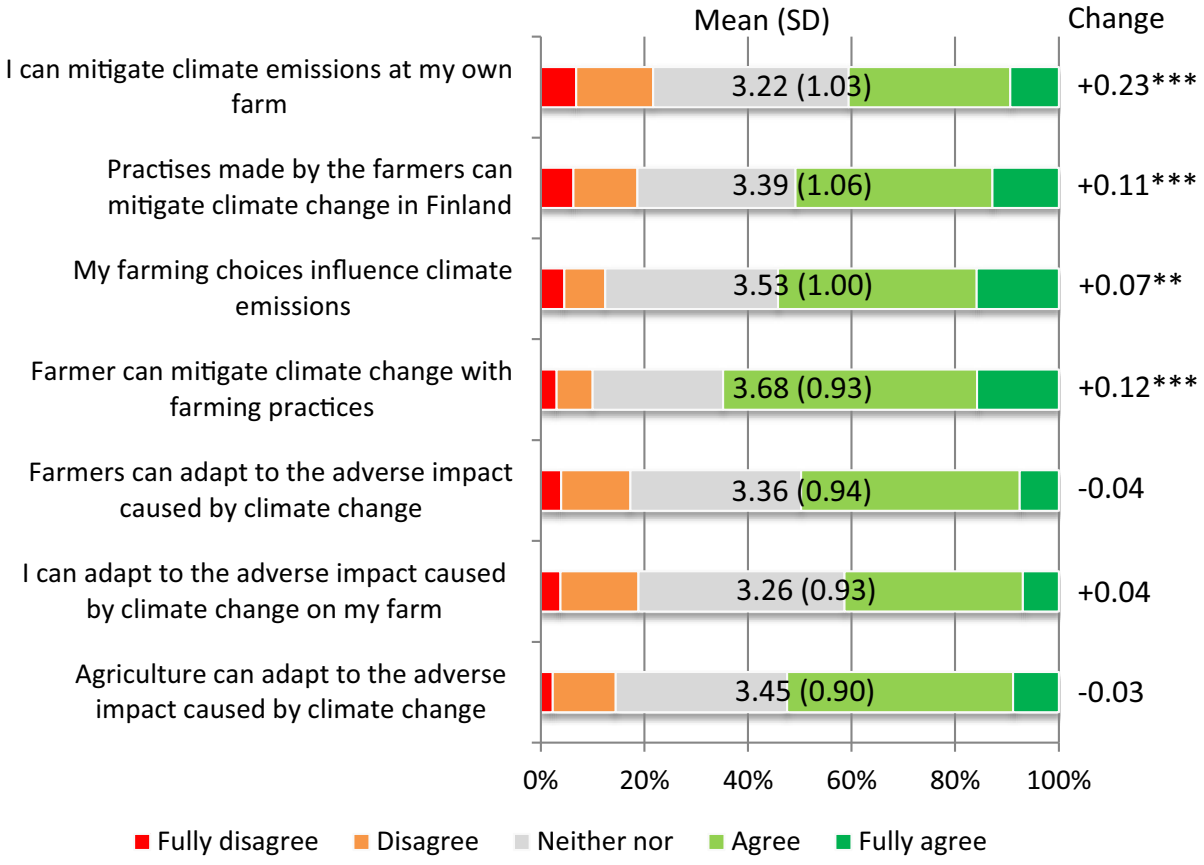

Fig. 4 The distribution, mean, and standard deviation (SD) of farmer's answers to questions related to their possibility to influence to climate change mitigation and adaptation shown in bars for $2018(N=4397)$. The respondents were asked "What do you think about the following statements?" Answers were measured by a 5point Likert scale ( $1=$ fully disagree, $2=$ disagree, $3=$ neither agree nor disagree, $4=$ agree, $5=$ fully agree). The same statements were repeated in 2020, and the change in mean and statistical significance for the respondents who responded to both surveys $(N=1966)$ is shown on the right. The statistically significant differences are indicated by $* * * P<0.001$, $* * P<0.01$, and $* P<0.05$ 
as were highly educated farmers compared to those with lower education and organic farmers compared to conventional ones. Farm size had no impact on the statements of mitigation potential at the general farmer's level, but at personal level, larger unit owners thought more often that they could mitigate at their own farm and that their farming choices influenced GHG emissions more than farmers with smaller units. Regionally, farmers from Åland were more positive on farmers' general level possibilities to mitigate than farmers from Western and Northern Finland. Changes from 2018 to 2020 within the background variable groups in mitigation possibility statements were positive in almost all groups (Appendix 10).

Farmer's own possibilities to mitigate climate change were more positive than those to adapt to it (Fig. 4, Appendix 3). Again, the personal opportunities were considered to be modest when compared to those at general farmer and sector levels (Fig. 4). Regarding personal adaptation, $41 \%$ of the respondents agreed that they can adapt to climate change impacts at their own farm, while $19 \%$ disagreed and $40 \%$ were indecisive. There was no change between the mean values of statements from 2018 to 2020 (Fig. 4).

Male respondents, organic producers and younger farmers saw adaptation possibilities more positively than female farmers, conventional producers and older respondents (Appendix 7). More highly educated farmers and larger farm owners trusted more in their possibilities to adapt than less educated farmers and small farm owners. There were no differences between farm types or regions. The changes in statement means were negligible from 2018 to 2020 (Appendix 10).

\subsection{Connections between climate change views and values}

Farmers who believed that climate change is of anthropogenic origin considered it a threat to both global and Finnish agriculture, felt responsibility for mitigation and adaptation actions, and considered possibilities to mitigate more positively than respondents who denied climate change to be of anthropogenic origin (all correlations are shown in Appendix 11). However, belief in anthropogenic origin did not associate with possibilities to adapt to climate change. From the personal values studied, only the universalism values correlated with belief of the anthropogenic origin of climate change. Farmers who believed that climate change is a great global threat, also tended to believe in anthropogenic origin of climate change.

Farmers who believed that climate change was an opportunity for Finnish agriculture also saw better opportunities for adaption and did not consider climate change to be such a serious threat. The view that climate change is a threat to Finnish agriculture correlated positively with anthropogenic climate change view, global threat to agriculture and responsibility for mitigation, but negatively with the view that climate change is an opportunity and the possibility to adapt. The highest correlations were found between responsibility for climate change mitigation and possibility to mitigate $(r=0.70)$. Farmers who felt more responsibility agreed that climate change was of anthropogenic origin and is a threat to agriculture both globally and locally, and that farmers have adaptation responsibilities and also possibilities. Positive correlation was found also between responsibility to mitigate and the three universalism values. Farmers who felt responsibility towards climate change adaptation considered that climate change is of anthropogenic origin, global threat to agriculture, mitigation responsibility and possibility and adaptation possibility. Low correlation was found between adaptation responsibility and the universalism values.

The farmers' view on their own possibilities to mitigate climate change correlated with anthropogenic climate change view, global and local threat to agriculture, mitigation 
responsibility, adaptation responsibility, adaptation possibility and the universalism values on a low level. Possibility to adapt to climate change correlated positively with climate change seen as an opportunity to Finnish agriculture, mitigation responsibility $(r=0.24)$ and adaptation responsibility and mitigation possibility. Low negative correlation was found between possibility to adapt and consideration of climate change as a threat to Finnish agriculture. Adaptation possibility had no meaningful correlations with any of the values in the study.

\section{Discussion}

\subsection{Farmers views on climate change}

While farmers were almost unanimous about climate change actually happening, views about its causes differed. According to Finnish farmers' views, climate change is not necessarily of human origin: $64 \%$ considered it to be either partly or as a whole due to natural causes (Fig. 1). In the USA, the share of uncertain and non-believers was around 32\% (Arbuckle Jr. et al. 2015), while in Finland it was only 3\%. Hence, Finnish farmers' overall belief in anthropogenic origin of climate change was much higher and more in line with other north European farmers, such as in Norway (Brobakk 2018).

Finnish farmers' views concerning climate change were of dual nature: risks for agriculture were agreed to be higher in a global scale than for Finland (Fig. 2). The farmers even recognized opportunities that global warming could provide to Finnish agriculture. In Finland, growing season is short and cool, so warming might, e.g., enables expansion of many current minor and novel crops as already experienced (Peltonen-Sainio and Jauhiainen 2020). Balancing between climate change-induced risks and opportunities has also been observed by US farmers (Niles et al. 2013; Takahashi et al. 2016). Our study, however, highlighted that the differences in farmers' views changed along psychological distance. More benefits were considered at the general agricultural level than farmer's personal level (Fig. 2). Psychological distance is often connected to mitigation and adaptation actions (Azadi et al. 2019; Haden et al. 2012; Spence et al. 2012), but according to this study, it may also impact farmers' views on opportunities provided by climate change.

In spite of the confusing juxtaposition of threats and opportunities, a large part of the Finnish farmers considered that the agricultural sector has responsibilities to mitigate climate change (Fig. 3). This agreed with the findings on German farmers (Jantke et al. 2020). Again, the responsibility was considered higher the further away the responsibility was compared to personal level. Adaptation and mitigation were somewhat separated in farmers' considerations, as previously reported (Arbuckle Jr. et al. 2013a; Haden et al. 2012). Finnish farmers were more positive about adaptation than mitigation responsibilities (Fig. 3). Adaptation measures were seen in the context of good agricultural practices and maintenance of soil conditions. Thereby, adaptation is close to everyday agricultural activities, whereas mitigation is an additional task without linkages to agricultural production per se.

Farmers in general thought that their possibilities for mitigation are rather high and that practices made by the farmers will have an effect on emission reduction (Fig. 4). On the other hand, their views on possibilities for adaptation were lower than for mitigation, though still quite good (Fig. 4, Appendix 3). This may be attributable to farmers' experiences on how hard it is to successfully cope with weather-related risks (Peltonen-Sainio et al. 2020). 
Farmers' climate change views differed depending on gender, education, farm size and farming system: women, highly educated farmers, small farm owners and organic producers were more concerned about climate change threats (Appendix 5) and also more in favour of climate change mitigation actions than men, lower educated farmers, bigger farm owners and conventional producers (Appendix 6). On the other hand, the latter group was more positive about climate change-driven opportunities for Finnish agriculture (Appendix 5) as well as possibilities to adapt to the changing risks (Appendix 7). Comprehensive research on the impact of background variables to farmers' climate change views is scarce. Liu et al. (2014), however, found that women had a higher tendency to support the existence and anthropogenic origins of climate change. Furthermore, research on other sectors than agriculture has shown women to be more positive towards climate change mitigation than men (Jansson and Dorrepaal 2015). This difference has been explained by gender role differences and social development, where women are more concerned about impacts to others and to the environment. Highly educated may have more comprehensive understanding of the multifaceted challenges brought by climate change, which may explain the differences between education levels shown in this study. Surprisingly, previous research has not always found the same trend with education among farmers (Eggers et al. 2015; Jørgensen and Termansen 2016; Liu et al. 2014) contrary to, e.g., Brobakk (2018). Organic producers have a value base that is more inclined towards environmental values and environmental protection than conventional farmers (Sorvali et al. 2020). This likely explains their stronger support for climate action, which was also found among German farmers (Jantke et al. 2020). The connection with farm size and climate change views has also been found in previous research (Jørgensen and Termansen 2016) without any clear reasoning. As the differences in Finland were often found between farms with $\geq 100$ ha and the rest, they may be attributable to higher business orientation in large farms. Research on farmers' values also showed that owners of larger farm units are less inclined towards environmental values than smaller unit owners (Sorvali et al. 2020), which may again be associated with higher business orientation.

Regional differences were not considerable, but Åland was more supportive towards mitigation responsibilities than the other regions (Appendix 6), though less so towards adaptation to increases in precipitation as well as local and regional drying of agricultural land (Appendix 6). This might be due to very different climatic conditions in archipelago compared to mainland Finland. Farm type was not an important factor determining the farmers' climate change views (Appendices 2-4). Along with previous research of Jørgensen and Termansen (2016), the youngest farmer generation was more sceptical about climate change and the threats it poses (Appendix 5), and so felt less frequently that it is their responsibility to mitigate climate change when compared to the middle aged farmers (Appendix 6). They were also most positive about their possibilities to adapt to changes (Appendix 7). This might be surprising as young people are otherwise reported to be extremely worried about climate change (Piispa and Myllyniemi 2019). However, "young" is more broadly considered in this study ( $<30$ years). Furthermore, the young farmers have practiced farming in "the presence of climate change" without having experienced the "good old days" of the older farmer generations.

\subsection{Shifts in climate change views from 2018 to 2020}

Farmers' views on climate change-induced opportunities for Finnish agriculture had become more positive from 2018 to 2020 (Fig. 2, Appendix 3), as have possibilities to mitigate climate 
change (Fig. 4, Appendix 3). However, their belief in anthropogenic origin of climate change became more negative, as also responsibility for adaptation to copy with changes in precipitation (Figs. 1 and 3, Appendix 3). Farmers' views on their responsibility to mitigate climate change showed a significant drop, but this result is highly uncertain due to research design. No change was found in statements concerning climate change threat for agriculture globally and locally, or statements concerning farmers' possibilities to adapt to climate change (Appendix 3).

Public climate change discussion related to agriculture was very modest in Finland before the first survey. However, shortly after the survey, climate change-related media coverage rose to a new record since its first peak in 2007 that subsequently collapsed (Lyytimäki 2020). Recently topics such as carbon farming and economic incentives have gained ground in public agenda (Lehtonen et al. 2020). It seems apparent that farmers' views on climate change have been affected by heated discussion, explaining why the interest towards climate changeinduced opportunities and possibilities to mitigate it has increased among farmers. On the other hand, farmers have felt that they were being blamed for causing climate change (YLE News 2019). This again might have caused a counter reaction within the farmer community, which explains the negative change in responses to the statement concerning mitigation responsibility. It might be that while knowledge about the roles of different sectors in mitigation has grown, farmers have also become increasingly concerned about being obliged to carry out mitigation efforts by themselves. This may partly explain the decrease in responsibility for mitigation, although bearing in mind the uncertainty of this result. The statements concerning responsibility for adaptation where the farmers' views had become more negative in 2020 were at high precipitation risks, which was previously one of the main climate-related concerns in Finland (Peltonen-Sainio et al. 2020). Summer 2017 was very rainy, yet drought was experienced during the two following growing seasons right after the 2018 survey. Hence, it is easy to understand the shifts in farmers' views on risks related to precipitation. This example highlights how recent experiences may cause shifts in farmers' views; i.e. farmers emphasize recent experiences over longer term ones.

Many changes were found within the different background variable groups when studying which groups had changed their views from 2018 to 2020 (Appendices 5-7). Women, < 30 and $\geq 71$ years old farmers, the education group "others", horticultural producers and farmers in Åland had not changed their views at all concerning anthropogenic climate change, opportunities of climate change and climate change as a threat statements (Appendix 8). With other groups and statements, generalizations are not possible due to a lack of any systematic changes.

\subsection{Connections between climate change views and values}

Farmers' high sense of responsibility for climate change mitigation was strongly connected to their felt possibilities to act to mitigate emissions (Appendix 11). Belief in anthropogenic origins of climate change, high notion of climate change risks for agriculture and environmental values were also connected to mitigation responsibility, i.e. farmers' willingness to mitigate. Similar results from USA (Arbuckle Jr. et al. 2013a, 2013b) and Sweden (Asplund 2016) emphasize the idea that if humans caused the problem, they also have the responsibility and means to fix it, but interchangeably changes caused by nature cannot be fixed by man. This again withdraws the responsibility of action.

Farmers' high notion of climate change as an opportunity for Finnish agriculture was tightly positively connected to possibility to adapt to climate change risks (Appendix 11) and 
negatively connected to climate change being a threat to Finnish agriculture. No connections were found between the climate change opportunity views and responsibility towards mitigation and adaptation, anthropogenic climate change belief, global climate change risk view and environmental values. This would imply that farmers who believe strongly that climate change will benefit Finnish agriculture do not see the connected risks. They may also be "technooptimists" and think that coping with emerging risks is easy, as was suggested by Gardezi and Arbuckle (2020). Hence, there is no need for specific, proactive mitigation and adaptation actions. Finnish farmers' personal experiences of the climate change-related risks for agriculture varied and many of the risks were rarely observed (Peltonen-Sainio et al. 2020). As Weber (2006) pointed out, personal experience of the risk strongly influences peoples' responses to it.

Climate change literature in agriculture has primarily focused on the risks that climate change will bring and the adaptive challenges the farmers will face (Haden et al. 2012; Takahashi et al. 2016). Less attention has been given to the opportunities (Peltonen-Sainio and Jauhiainen 2020) that Nordic and boreal countries may face. This is understandable due to the many negative consequences that climate change will bring globally. The outcomes of the surveys highlighted some confusion among farmers who are expected to both combat climate change and simultaneously adapt and benefit from its impacts such as longer growing season and better opportunities for diverse crop choices, which both are already recorded in Finland (Kaukoranta and Hakala 2008, Peltonen-Sainio and Jauhiainen 2020). Uncertainty concerning climate change impacts has previously been reported as a reason for farmers' low willingness to change their practices (Morton et al. 2017). In Finland the adaptation to both benefit from but also cope with emerging risks may cause even more confusion among farmers.

Values seem to be of importance in constructing farmers' climate change views as there was positive connection between environmental values and anthropogenic climate change belief, view of a global threat of climate change to agriculture, responsibility towards mitigation and adaptation as well as possibility to mitigate (Appendix 11). This finding is in line with Price and Leviston (2014) who studied how values are connected to pro-environmental land management in Australia. Sanderson et al. (2018) did not find any direct correlation between environmental values and climate change beliefs among farmers in the USA. However, our results show a direct positive correlation for Finnish farmers. "Belief matters in climate change action" stated Vainio and Paloniemi (2013) for general Finnish public and the same can be said for Finnish farmers. To put it short, climate change is constructed differently by different individuals (Hulme 2009) and the challenges it brings cannot be understood or solved by only considering a single perspective.

\section{Conclusion}

This research has shown that farmers have very differing beliefs concerning climate change and they view also the connected risks and opportunities differently. Similarly, farmers' views on their responsibilities to act differ as do their own possibilities to adapt and mitigate. Thus, understanding farmers' beliefs, views, and also values is elemental for success in mitigation and adaptation in agriculture. Without this understanding, it is impossible to draft policy measures that will be accepted and thoroughly implemented by farmers. In general, the Finnish farmers seem to have a very high awareness of climate change, a strong notion that action must be taken and that their actions will have an effect. This serves as a good starting point for climate action in agriculture in Finland. 
As highly educated, women, small farm owners, and organic producers support climate mitigation the most, these groups will probably also be in the frontline of climate action in the future and should be encouraged to act as examples for others. Special attention should be paid for young farmers, as they will be responsible for agricultural production in the long term, not least as they have more doubts towards climate action than the other age groups. High education was a clear indicator of support towards climate change mitigation, which highlights the importance of education in combatting climate change in the future.

Acknowledging that mitigation and adaptation seem to be separate entities for farmers is important for successful climate change policies and their implementation in the future. Adaptation is best achieved at the farm scale, as it requires focusing on maintaining good soil conditions to support long-term resilience. Farmers' personal responsibilities and possibilities to adapt should be communicated in the context of the actual practices. On the other hand, achievements in mitigation are much more difficult without changes in agricultural policies as mitigation requires land use changes, not only changes in management practices. For mitigation, stronger upper-level guidance, such as regulations coupled with incentives, could be favoured. Further research is needed to elaborate more the barriers and acceptability of concrete mitigation practices in the high-latitude agriculture context.

The controversy caused by climate change opportunities and risks challenges the aspiration for consensus and acceptance of climate measures as it causes confusion among farmers. The opportunities and risks should be discussed hand in hand to take a step towards more coherent and comprehensive understanding of climate change in high-latitude agriculture. While Finnish agriculture is expected to benefit from the warming climate, unpredictable weather events, such as drought and heavy rains, and emerging pests and diseases may outweigh the opportunities, if not taken seriously and responded in a timely manner. Climate policy would benefit from thorough research on farmers' views over this controversy of risks and opportunities.

The longitudinal method of this study showed that farmers respond to public discussion and new emerging ideas and policy by changing their views. The farmer community and other agricultural stakeholders should all participate equally, and from the very beginning, to the dialogue around the future climate actions in agriculture to avoid confusion and unnecessary misunderstandings.

Supplementary Information The online version contains supplementary material available at https://doi.org/ 10.1007/s10584-021-03020-4.

Author contribution Conceptualization: Jaana Sorvali; Methodology: Jaana Sorvali; Formal analysis and investigation: Janne Kaseva, Jaana Sorvali; Writing - original draft preparation: Jaana Sorvali; Writing - review and editing: Jaana Sorvali, Janne Kaseva and Pirjo Peltonen-Sainio; Funding acquisition: Pirjo Peltonen-Sainio, Jaana Sorvali; Resources: Jaana Sorvali; Supervision: Pirjo Peltonen-Sainio.

Funding Open access funding provided by Natural Resources Institute Finland (LUKE). The work was financed by the European Commission Life-Programme and Natural Resources Institute Finland (Luke) as a part of a consortium project called Optimising Agricultural Land Use to Mitigate Climate Change (OPAL-Life, LIFE14 CCM/FI/000254; this paper only reflects the authors' view and the EASME/Commission is not responsible for any use that may be made of the information it contains). The work was supported also by the Academy of Finland through DivCSA (decision no. 316215). 
Data availability The data that support the findings of this study are available on request from the corresponding author. The data are not publicly available due to privacy or ethical restrictions.

\section{Declarations}

Conflict of interest The authors declare no competing interests.

Open Access This article is licensed under a Creative Commons Attribution 4.0 International License, which permits use, sharing, adaptation, distribution and reproduction in any medium or format, as long as you give appropriate credit to the original author(s) and the source, provide a link to the Creative Commons licence, and indicate if changes were made. The images or other third party material in this article are included in the article's Creative Commons licence, unless indicated otherwise in a credit line to the material. If material is not included in the article's Creative Commons licence and your intended use is not permitted by statutory regulation or exceeds the permitted use, you will need to obtain permission directly from the copyright holder. To view a copy of this licence, visit http://creativecommons.org/licenses/by/4.0/.

\section{References}

Altea L (2020) Perceptions of climate change and its impacts: a comparison between farmers and institutions in the Amazonas region of Peru. Clim Dev 12(2):134-146. https://doi.org/10.1080/17565529.2019.1605285

Arbuckle JG Jr, Morton LW, Hobbs J (2013a) Farmer beliefs and concerns about climate change and attitudes toward adaptation and mitigation: evidence from Iowa. Clim Chang 118(3-4):551-563. https://doi.org/10. 1007/s10584-013-0700-0

Arbuckle JG Jr, Prokopy LS, Haigh T, Hobbs J, Knoot T, Knutson C et al (2013b) Climate change beliefs, concerns, and attitudes toward adaptation and mitigation among farmers in the Midwestern United States. Clim Chang 117(4):943-950. https://doi.org/10.1007/s10584-013-0707-6

Arbuckle JG Jr, Morton LW, Hobbs J (2015) Understanding farmer perspectives on climate change adaptation and mitigation: the roles of trust in sources of climate information, climate change beliefs, and perceived risk. Environ Behav 47(2):205-234. https://doi.org/10.1177/0013916513503832

Arneth A, Barbosa H, Benton T, Calvin K, Calvo E, Connors S, Cowie A (2019) Climate change and land. an IPCC special report on climate change, desertification, land degradation, sustainable land management, food security, and greenhouse gas fluxes in terrestrial ecosystem. IPCC. Retrieved from https://www.ipcc.ch/ report/srccl/

Asplund T (2016) Natural versus anthropogenic climate change: Swedish farmers' joint construction of climate perceptions. Public Underst Sci 25(5):560-575. https://doi.org/10.1177/0963662514559655

Azadi Y, Yazdanpanah M, Mahmoudi H (2019) Understanding smallholder farmers' adaptation behaviors through climate change beliefs, risk perception, trust, and psychological distance: evidence from wheat growers in Iran https://doi.org/10.1016/j.jenvman.2019.109456

Bardi A, Schwartz SH (2003) Values and behavior: strength and structure of relations. Personal Soc Psychol Bull 29(10):1207-1220. https://doi.org/10.1177/0146167203254602

Barnes AP, Toma L (2012) A typology of dairy farmer perceptions towards climate change. Clim Chang 112(2): 507-522. https://doi.org/10.1007/s10584-011-0226-2

Brobakk J (2018) A climate for change? Norwegian farmers' attitudes to climate change and climate policy. World Political Science 14(1):55-79. https://doi.org/10.1515/wps-2018-0003

Buys L, Miller E, van Megen K (2012) Conceptualising climate change in rural Australia: community perceptions, attitudes and (in)actions. Reg Environ Chang 12(1):237-248. https://doi.org/10.1007/s10113011-0253-6

de Winter JCF, Dodou D (2010) Five-point Likert items: T-test versus Mann-Whitney-Wilcoxon. Pract Assess Res Eval 15:1-7

Dunlap RE, Van Liere KD, Mertig AG, Jones RE (2000) Measuring endorsement of the new ecological paradigm: a revised NEP scale. J Soc Issues 56(3):425-442

Eggers M, Kayser M, Isselstein J (2015) Grassland farmers' attitudes toward climate change in the North German plain. Reg Environ Chang 15(4):607-617. https://doi.org/10.1007/s10113-014-0672-2

Gardezi M, Arbuckle JG (2020) Techno-optimism and farmers' attitudes toward climate change adaptation. Environ Behav 52(1):82-105. https://doi.org/10.1177/0013916518793482 
Haden VR, Niles MT, Lubell M, Perlman J, Jackson LE (2012) Global and local concerns: what attitudes and beliefs motivate farmers to mitigate and adapt to climate change? PLoS One 7(12). https://doi.org/10.1371/ journal.pone.0052882

Hansla A, Gamble A, Juliusson A, Gärling T (2008) The relationships between awareness of consequences, environmental concern, and value orientations. J Environ Psychol 28(1):1-9. https://doi.org/10.1016/j.jenvp. 2007.08.004

Hitayezu P, Wale E, Ortmann G (2017) Assessing farmers' perceptions about climate change: a double-hurdle approach. Clim Risk Manag 17:123-138. https://doi.org/10.1016/j.crm.2017.07.001

Hulme, M. (2009). Why we disagree about climate change. Understanding controversy, Inaction and Opportunity. Cambridge University Press

IPCC (2018) Global Warming of $1.5^{\circ} \mathrm{C}$. An IPCC Special Report on the impacts of global warming of $1.5^{\circ} \mathrm{C}$ above pre-industrial levels and related global greenhouse gas emission pathways, in the context of strengthening the global response to the threat of climate change, sustainable development, and efforts to eradicate poverty [Masson-Delmotte, V., P. Zhai, H.-O. Pörtner, D. Roberts, J. Skea, P.R. Shukla, A. Pirani, W. Moufouma-Okia, C. Péan, R. Pidcock, S. Connors, J.B.R. Matthews, Y. Chen, X. Zhou, M.I. Gomis, E. Lonnoy, T. Maycock, M. Tignor, and T. Waterfield (eds.)]. In Press

Jansson J, Dorrepaal E (2015) Personal norms for dealing with climate change: results from a survey using moral foundations theory. Sustain Dev 23(6):381-395. https://doi.org/10.1002/sd.1598

Jantke K, Hartmann MJ, Rasche L, Blanz B, Schneider UA (2020) Agricultural greenhouse gas emissions: knowledge and positions of German farmers. Land 9(5). https://oi.org/10.3390/LAND9050130

Jørgensen SL, Termansen M (2016) Linking climate change perceptions to adaptation and mitigation action. Clim Chang 138(1-2):283-296. https://doi.org/10.1007/s10584-016-1718-x

Kabir MJ, Cramb R, Alauddin M, Roth C, Crimp S (2017) Farmers' perceptions of and responses to environmental change in southwest coastal Bangladesh. Asia Pac Viewp 58(3):362-378. https://doi.org/ 10.1111/apv.12165

Karki S, Burton P, Mackey B (2020) The experiences and perceptions of farmers about the impacts of climate change and variability on crop production: a review. Clim Dev 12(1):80-95. https://doi.org/10.1080/ 17565529.2019.1603096

Kaukoranta T, Hakala K (2008) Impact of spring warming on sowing times of cereal, potato and sugar beet in Finland. Agric Food Sci 17:165-176

Khanal U, Wilson C, Hoang V, Lee B (2018) Farmers' adaptation to climate change, its determinants and impacts on rice yield in Nepal. Ecol Econ 144:139-147. https://doi.org/10.1016/j.ecolecon.2017.08.006

Lehtonen H, Saarnio S, Rantala J, Luostarinen S, Maanavilja L, Heikkinen J, Soini K, Aakkula J, Jallinoja M, Rasi S, Niemi J (2020) Maatalouden ilmastotiekartta. Tiekartta kasvihuonekaasupäästöjen vähentämiseen Suomen maa-taloudessa. Abstract in English. MTK/Natural Resources Institute Finland. Retrieved from: https://www.mtk.fi/documents/20143/0/Ilmastotiekartta+-raportti+15072020+\%281\%29.pdf/bc1197e36844-62e3-0259-931da255072b?t=1594791153902

Liu Z, Smith WJ Jr, Safi AS (2014) Rancher and farmer perceptions of climate change in Nevada, USA. Clim Chang 122(1-2):313-327. https://doi.org/10.1007/s10584-013-0979-x

Lyytimäki J (2020) Ilmastonmuutos isosti otsikoissa - kirittääkö uutisointi kestävyysmurrokseen? Yhteiskuntapolitiikka. 2:191-196

Ministry of Environment (2017) Government report on medium-term climate change policy plan for 2030, towards climate-smart day-to-day living. (No. 21). Ministry of Environment. Retrieved from http://urn.fi/ URN:ISBN:978-952-11-4752-4

Morton LW, Roesch-McNally G, Wilke AK (2017) Upper Midwest farmer perceptions: too much uncertainty about impacts of climate change to justify changing current agricultural practices. J Soil Water Conserv 72(3):215-225. https://doi.org/10.2489/jswc.72.3.215

Natural Resources Institute Finland (2019) Structure of agricultural and horticultural enterprises. Retrieved from https://stat.luke.fi/en/structure-of-agricultural-and-horticultural-enterprises

Nguyen TPL, Seddaiu G, Virdis SGP, Tidore C, Pasqui M, Roggero PP (2016) Perceiving to learn or learning to perceive? Understanding farmers' perceptions and adaptation to climate uncertainties. Agric Syst 143:205216. https://doi.org/10.1016/j.agsy.2016.01.001

Niles MT, Lubell M, Haden VR (2013) Perceptions and responses to climate policy risks among California farmers. Glob Environ Chang 23(6):1752-1760. https://doi.org/10.1016/j.gloenvcha.2013.08.005

Niles MT, Brown M, Dynes R (2016) Farmer's intended and actual adoption of climate change mitigation and adaptation strategies. Clim Chang 135(2):277-295. https://doi.org/10.1007/s10584-015-1558-0

Peltonen-Sainio P, Jauhiainen L (2020) Large zonal and temporal shifts in crops and cultivars coincide with warmer growing seasons in Finland. Reg Environ Chang 20:89. https://doi.org/10.1007/s10113-020-01682-x 
Peltonen-Sainio P, Palosuo T, Ruosteenoja K, Jauhiainen L, Ojanen H (2018) Warming autumns at high latitudes of Europe: an opportunity to lose or gain in cereal production? Reg Environ Chang 18(5):1453-1465. https://doi.org/10.1007/s10113-017-1275-5

Peltonen-Sainio P, Sorvali J, Kaseva J (2020) Winds of change for farmers: matches and mismatches between experiences, views and the intention to act. Clim Risk Manag 27. https://doi.org/10.1016/j.crm.2019.100205

Piispa M, Myllyniemi S (2019) Nuoret ja ilmastonmuutos. Tiedot, huoli ja toiminta Nuorisobarometrien valossa. Yhteiskuntapolitiikka 84:1

Price JC, Leviston Z (2014) Predicting pro-environmental agricultural practices: the social, psychological and contextual influences on land management. J Rural Stud 34. https://doi.org/10.1016/j.jrurstud.2013.10.001

Roco L, Engler A, Bravo-Ureta BE, Jara-Rojas R (2015) Farmers' perception of climate change in Mediterranean Chile. Reg Environ Chang 15(5):867-879. https://doi.org/10.1007/s10113-014-0669-X

Rokeach M (1973) The nature of human values. Free Press, New York

Sagiv L, Roccas S, Cieciuch J, Schwartz SH (2017) Personal values in human life. Nat Hum Behav 1(9):630639. https://doi.org/10.1038/s41562-017-0185-3

Sanderson MR, Bergtold JS, Heier Stamm JL, Caldas MM, Ramsey SM, Aistrup J (2018) Climate change beliefs in an agricultural context: what is the role of values held by farming and non-farming groups? Clim Chang 150(3-4):259-272. https://doi.org/10.1007/s10584-018-2283-2

Schattman RE, Méndez VE, Merrill SC, Zia A (2018) Mixed methods approach to understanding farmer and agricultural advisor perceptions of climate change and adaptation in Vermont, United States. Agroecol Sustain Food Syst 42(2):121-148. https://doi.org/10.1080/21683565.2017.1357667

Schultz PW, Gouveia VV, Cameron LD, Tankha G, Schmuck P, Franek M (2005) Values and their relationship to environmental concern and conservation behavior. J Cross-Cult Psychol 36(4):457-475. https://doi.org/ 10.1177/0022022105275962

Schwartz SH (1994) Are there universal aspects in the structure and contents of human values? J Soc Issues 50(4):19-45

Schwartz SH, Cieciuch J, Vecchione M, Davidov E, Fischer R, Beierlein C et al (2012) Refining the theory of basic individual values. J Pers Soc Psychol 103(4):663-688. https://doi.org/10.1037/a0029393

Sorvali J, Vainio A, Kaseva J, Verkasalo M, Peltonen-Sainio P (2020) Heterogeneity in value priorities of the Finnish farmers - time to stop thinking of farmers as inherently conservative and traditional. Journal of Community \& Applied Social Psychology Under review

Spence A, Poortinga W, Pidgeon N (2012) The psychological distance of climate change. Risk Anal 32(6):957972. https://doi.org/10.1111/j.1539-6924.2011.01695.x

Stern PC (2000) New environmental theories: toward a coherent theory of environmentally significant behavior. J Soc Issues 56(3):407-424. https://doi.org/10.1111/0022-4537.00175

Takahashi B, Burnham M, Terracina-Hartman C, Sopchak AR, Selfa T (2016) Climate change perceptions of NY state farmers: the role of risk perceptions and adaptive capacity. Environ Manag 58(6):946-957. https:// doi.org/10.1007/s00267-016-0742-y

Vainio A, Paloniemi R (2013) Does belief matter in climate change action? Public Underst Sci 22(4):382-395. https://doi.org/10.1177/0963662511410268

Weber EU (2006) Experience-based and description-based perceptions of long-term risk: why global warming does not scare us (yet). Clim Chang 77(1-2):103-120. https://doi.org/10.1007/s10584-006-9060-3

Weber EU, Stern PC (2011) Public understanding of climate change in the United States. Am Psychol 66(4): 315-328. https://doi.org/10.1037/a0023253

YLE News (2019) Maanviljelijän elämä synkkeni, kun hänen sanottiin olevan syypää ilmastonmuutokseen: "Haluaisin vain sulkeutua omaan kuplaani ja olla kuuntelematta". Maanviljelyä syyllistävä ilmastonmuutoskeskustelu aiheuttaa nyt eniten ahdistusta suomalaisille maanviljelijöille. (Farmer's life became gloomy when the she was said to be to blame for climate change: "I would just like to go into my own bubble and not listen." The climate change debate that blames agriculture is now causing the most anxiety to Finnish farmers.) YLE News 19.8.2019. Retrieved from: https://yle.fi/uutiset/3-109223

Publisher's note Springer Nature remains neutral with regard to jurisdictional claims in published maps and institutional affiliations. 